Fitria Wulandari, Aldri Frinaldil Pengaruh Kepemimpinan Kepala Dinas Perempuan terhadap Budaya Kerja Pegawai pada Dinas Lingkungan Hidup Kabupaten Dharmasaya

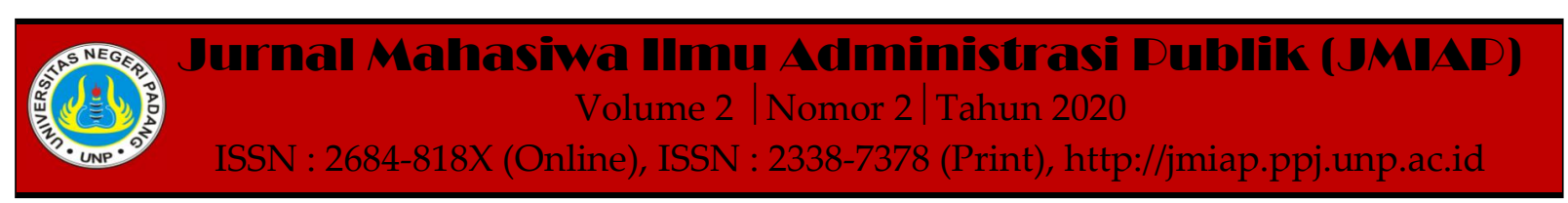

\title{
PENGARUH KEPEMIMPINAN KEPALA DINAS PEREMPUAN TERHADAP BUDAYA KERJA PEGAWAI PADA DINAS LINGKUNGAN HIDUP KABUPATEN DHARMASAYA
}

\author{
Fitria Wulandari ${ }^{1(a)}$, Aldri Frinaldi ${ }^{2(b)}$ \\ ${ }^{1}$ Jurusan Ilmu Administrasi Negara, Universitas Negeri Padang \\ ${ }^{2}$ Jurusan Ilmu Administrasi Negara, Universitas Negeri Padang \\ a)culanf2301@gmail.com, ${ }^{b)}$ aldri@fis.unp.ac.id
}

\begin{abstract}
The purpose of this study was to analyze how much influence the leadership of the female department head on the work culture of employees at the Environmental Service Office of Dharmasraya Regency, West Sumatra. This research uses quantitative methods. The sampling technique was done using purposive sampling. Quantitative data were collected using a Likert scale questionnaire that had been tested for validity and reliability. The total population of employees of the Environmental Service Office of Dharmasraya Regency is 62 people, with this study researching with a total sampling technique. The reason for this research is because there are very few women leaders in government institutions in Indonesia, especially in Dharmasraya Regency. In this study, it can be seen that there is a positive influence of the leadership of the female department head on the work culture of employees that have been tested with the T-test, and a small significance value of 0.00 is obtained from 0.05 and the percentage contribution of variable X to $Y$ is $19.6 \%$. The value stated in this study is that the better the leadership abilities, the better the employee's work culture.
\end{abstract}

Keywords : Leadership, Work Culture, Feminism-Maskulin

Corresponding author.Email.culanf2301@gmail.com,aldri@fis.unp.ac.id

How to cite this article. Wulandari, F \& Frinaldi, A. (2020). Pengaruh Kepemimpinan Kepala Dinas Perempuan terhadap Budaya Kerja Pegawai pada Dinas Lingkungan Hidup Kabupaten Dharmasaya. Jurnal Mahasiwa Ilmu Administrasi Publik (JMIAP) Jurusan Ilmu Administrasi Negara Fakultas Ilmu Sosial Universitas Negeri Padang, Volume 2 (2), Hal. 108-115.

http://jmiap.ppj.unp.ac.id

ISSN : 2684-818X (Online), ISSN : 2338-7378 (Print)

Copyright $\bigcirc 2020$. Published by Pusat Kajian-Pemberdayaan dan Pelayanan Masyarakat (PK-P2M) FIS UNP Padang 
Fitria Wulandari, Aldri Frinaldil Pengaruh Kepemimpinan Kepala Dinas Perempuan terhadap Budaya Kerja Pegawai pada Dinas Lingkungan Hidup Kabupaten Dharmasaya

\section{PENDAHULUAN}

Kepemimpinan merupakan suatu konteks yang selalu menarik apabila dibahas. Kepemimpinan dalam suatu organisasi merupakan kata kunci dan kata kerja utama untuk mencapai tujuan suatu organisasi. Kepemimpinan adalah suatu hal yang harus dimiliki oleh setiap individu. Kepiawaian seorang pemimpin ditentukan dalam pengaruhnya, semangat dan kegairahan terhadap kerjanya serta tingkat prestasi dari suatu organisasi ditentukan oleh kepemimpinan pemimpinnya.

Pemimpin adalah seseorang yang memiliki kepandaian dan kelebihan khususnya dalam mempengaruhi bawahan untuk mencapai tujuan. Ketika suatu organisasi didominasi oleh kaum laki-laki yang merupakan sebagai pemimpin guna mencapai tujuan organisasi dapat dikatakan sangat kuat. Namun ternyata, perempuan juga memiliki potensi yang tidak kalah daripada laki-laki dalam hal memimpin. Kepemimpinan tidak mungkin terlepas dari seseorang yang berperan sebagai pemimpin. Hal ini dapat dilihat dari pekerjaan yang dahulunya didominasi oleh laki-laki sekarang dapat dikerjakan oleh perempuan dengan sangat baik mulai dari dinas, sopir, driver alat berat, mandor pertambangan, pengisian bahan bakar dan masih banyak lainnya(SM and Naumi 2019).

Di Indonesia masyarakat beranggapan bahwa perempuan tidak pantas menjadi seorang pemimpin, masyarakat menganggap bahwasanya wanita hanya perlu bekerja di rumah saja, dan yang pantas menjabat seorang pemimpin hanyalah kaum laki-laki. Dilihat dalam hal kepemimpinan, minimnya seorang perempuan yang berperan sebagai pemimpin, hal ini terbukti dalam pemilihan DPR tahun 2019 sebanyak 118 kursi atau $21 \%$ dari total 575 Kursi DPR diisi oleh perempuan. Sedangkan sudah banyak negara maju yang mengalakkan kampanye emansipasi wanita.

Kepemimpinan perempuan di Indonesia dapat kita lihat lebih detail terkhususnya pada daerah Sumatera Barat. Pada daerah
Provinsi Sumatera Barat yang sangat kita ketahui dan kita kenal merupakan salah satu daerah yang kental dengan adat istiadatnya, merupakan keruturunan yang bergariskan Matrilinear (garis keturunan berdasarkan garis ibu) yang bahkan memposisikan seorang perempuan lebih tinggi dari kedudukan laki-laki, khususnya dalam hal keluarga dan penguasaan harta pusaka tinggi. Kapabelitas perempuan menjadi seorang pemimpin dinilai dari pengalaman dalam mengurus masalah dalam masyarakat, baik sewaktu dalam rumah tangga, maupun organisasi. Data yang diperoleh dari Badan Pusat Statistik (BPS) Sumatera Barat pada Mei 2020, jumlah persentase perempuan sebagai tenaga profesional adalah 55,48\%. Persentase keterlibatan perempuan ini dikategorikan tinggi, karena sudah melebihi 50\% banyak tenaga profesional laki-laki.

Pada dasarnya perempuan tidak memiliki banyak peran sebagai seorang yang mempunyai keahlian dalam memimpin dan pengambilan keputusan, khususnya pada ranah pemerintahan Kabupaten Dharmasraya. Kecenderungan kemajuan yang dialami perempuan merupakan bagian dari sebuah fenomena yang sangat diperhatikan. Saat ini perempuan sudah diperbolehkan menikmati semua fasilitas dan pendidikan layaknya seperti yang dirasakan oleh kaum laki-laki pada umumnya, dan tidak hanya itu perempuanpun telah memulai karir untuk bekerja di luar rumah tangga seperti halnya ranah birokrasi. Berkembangnya pemahaman setiap individu yang semakin maju merupakan salah satu situasi atau keaadan yang akan menjadi pendorong yang akan mengakibatkan kaum perempuan mengalami banyak kemajuan (Fitri, Frinaldi, and Erianjoni 2019).

Peningkatan kontribusi perempuan dalam birokrasi pemerintah Kabupaten Dharmasraya dapat kita ketahui hasilnya dari jumlah pegawai perempuan yang kini sudah mulai mampu mengalahkan jumlah pegawai laki-laki. Hal tersebut dapat kita lihat pada grafik di bawah ini: 
Fitria Wulandari, Aldri Frinaldil Pengaruh Kepemimpinan Kepala Dinas Perempuan terhadap Budaya Kerja Pegawai pada Dinas Lingkungan Hidup Kabupaten Dharmasaya

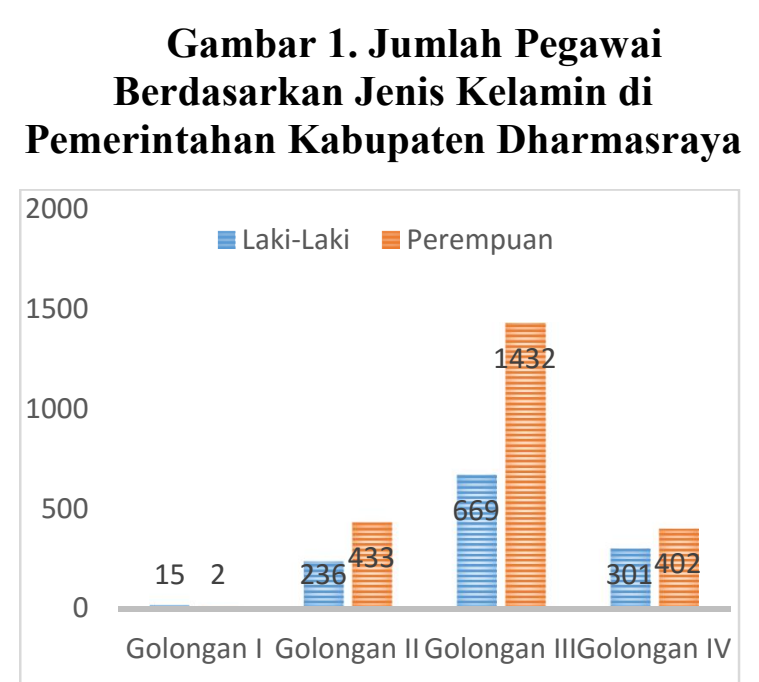

Sumber: Dharmasraya Dalam Angka (2019)

Data di atas meyakinkan kita bahwa banyaknya pegawai perempuan yang terjun ke ranah birokrasi Kabupaten Dharmasraya sudah melewati batas banyaknya pegawai laki-laki, terutama pada golongan II,III dan IV. Pada golongan II, tingkatan angkat pada pegawai perempuan adalah 433 orang yang sudah mengejar jumlah pegawai laki-laki yang berjumlah 236 orang. Sama halnya pada golongan III yang sudah semakin jauh tertinggal jumlah pegawai laki-laki, yang mana jumlah perempuan adalah 1.423 orang, dan pegawai laki-laki sebanyak 669 orang. Begitu pula pada golongan IV, meski jumlah pegawai perempuan menurun dari golongan II dan II namun jumlah pegawai prerempuan tetap tinggi pada jumlah pegawai laki-laki, yang mana jumlah pegawai perempuan 402 orang, sedangkan pegawai laki-laki berjumlah 301 orang. Tingkat pendidikan yang cukup tinggi merupakan salah satu faktor keberhasilan dan acuan yang menyebabkan jumlah perempuan mampu lebih unggul dari pada laki-laki dalam status kepegawaian.

Dari semua besaran yang di ungkapkan di atas bahwasanya jumlah pegawai perempuan lebih besar dari pada laki-laki, tampaknya itu semua tidak terjadi pada tingkatan teratas yaitu pemimpin. Semakin tinggi tingkatan dalam suatu instansi dalam birorkasi Pemerintah Kabupaten Dharmasraya maka semakin sedikit pula jumlah perempuan. Hal itu dapat terlihat dari tabel dibawah ini:

Tabel 1. Jumlah Perempuan dalam Jabatan di Kabupaten Dharmasraya

\begin{tabular}{clcc}
\hline No & Instansi & $\begin{array}{c}\text { Laki- } \\
\text { Laki }\end{array}$ & Perempuan \\
\hline 1 & $\begin{array}{l}\text { Sekretariat } \\
\text { Daerah }\end{array}$ & 2 & 0 \\
2 & $\begin{array}{l}\text { Sekretariat } \\
\text { DPRD }\end{array}$ & 1 & 0 \\
3 & Inspektorat & 1 & 0 \\
4 & Dinas & 16 & 3 \\
5 & Badan & 4 & 0 \\
6 & Kantor & 1 & 0 \\
7 & Rumah Sakit & 1 & 0 \\
\hline & Total & $\mathbf{2 5}$ & $\mathbf{3}$ \\
\hline
\end{tabular}

Sumber data:

Dharmasraya.go.id/OPD/KAbupaten/Dhar masraya/2020.

Dari table di atas dapat kita lihat bahwasanya jumlah pemimpin perempuan pada pemerintahan Kabupaten Dharmasraya sangat minim, yakni hanya 3 orang dan jumlah pemimpin laki-laki sangat berada jauh dari perempun, bahkan perempuan tidak sampai mencapai $50 \%$ dari jumlah laki-laki yang menjadi pemimpin.

Dari semua data di atas dapat kita ambil kesimpulan bahwa benar telah terjadi pengambangan keterlibatan kaum perempuan pada birokrasi pemerintahan Kabupaten Dharmasraya, semua ini bisa kita lihat dari besarnya keikutsertaan pegawai perempuan. Namun semua peningkatan yang terjadi bukan berarti apaapa, yang mana keikutsertaan perempuan tidak terlibat dalam hal kepemimpinan. Data jumlah pimpinan di birokrasi Pemerintah Kabupaten Dharmasraya menjelaskan bahwasanya besaran jumlah perempuan yang berprofesi sebagai seorang pemimpin saat ini tengah tertinggal jauh. Oleh sebab itu, meningkatnya keterlibatan kaum perempuan hanya mengarah pada tingkat staf, sedangkan dalam hal 
mempimpin atau pengambil keputusan masih sedikit

Banyak hal yang akan mempengaruhi kepemimpinan dari atasan, maka dari itu kepemimpinan merupakan suatu cara penjamin mutu dari pegawai, faktor yang berkaitan dengan kepemimpinan agar dapat terpenuhi salah satu faktornya mempengaruhi ialah budaya kerja pegawai. Budaya kerja pegawai merupakan hasil dari bentuk kepemimpinan seorang pemimpin dalam suatu organisasi. Dalam kehidupan birokrasi budaya kerja ialah suatu gambaran yang sangat perpengaruh untuk diterapkan dalam berorganisasi, khususnya organisasi pemerintah. Program-program pemerintahan dan pembangunan merupakan salah satu hal yang menjadi fokus budaya kerja pada sumber daya manusia untuk diimplementasikan. Budaya kerja muncul akibat dari ketidakpuasan masyarakat ataupun pegawai terhadap hasil maupun pencapaian tujuan yang kurang memuaskan. Hal ini biasanya dipicu oleh cara kerja birokrasi yang terkenal berbelitbelit, kurang terbuka pada masyarakat, lamban dalam bekerja, kaku, malas mengambil inisiatif diluar peraturan, cenderung menunggu atasan, kurang percaya pada kemampuan orang serta suasana batin dan mood yang berubahubah. Dan pada akhirnya sikap-sikap aparatur bersebut mengakibatkan tidak tercapainya tujuan yang ditetapkan, dan berakibat pada kekecewakan masyarakat dan tidak mampu memenuhi tuntutan kebutuhan masyarakat di masa depan.

Kementrian Pemberdayaan Aparatur Negara (Menpan) membuat pedoman pengembangan budaya kerja aparatur negara sebagi acuan untuk diterapkan yang akan menjadi acuan pada instansi pemerintah. Terkait budaya kerja di lingkungan Dinas Lingkungan Hidup Kabupaten Dharmasraya, bisa dilihat dari kebisaannya, misal dalam keseharian semua pegawai menebarkan senyum, sapa kepada pemimpin rekan kerja maupun masyarakat, mempunyai integritas pada pekerjaan yakni keselarasan hati dan pikiran, perkataan dan perilaku yang baik dan benar. Professional dengan bekerja disiplin, kompeten, tepat waktu dan hasil yang terbaik. Inovatif dengan mengkreasikan hal yang baru, tanggung jawab terhadap pekerjaan dan menjadi contoh yang baik untuk bawahan serta masyarakat.

Budaya kerja mempunyai pengaruh yang kuat dalam membuat sutau perubahan dalam suatu organisasi, yang meliputi tiga gagasan utama yang pertama adala tujuan, yang kedua budaya yang kuat karena akan menciptakan motivasi yang baru dan yang ketiga budaya yang kuat akan memberikan struktur dan control yang menumbuhkan inovasi. Maka dari itu perlu pembenahan yang dimulai dari seorang pemimpin baik sikap dan tingkah laku yang ditiru oleh bawahannya, sehingga menentukan cara tersendiri dalam menjalankan satuan kerja atau organisasi. Perlu adanya pembenahan cara kerja yang lebih inovatif, lebih efektif dan efisien, lebih dekomratis, lebih fleksibel dan menghilangkan kebiasaankebiasaan cara kerja lama yang sekiranya akan mengahalangi tercapainya tujuan organisasi.

\section{TINJAUAN PUSTAKA \\ Konsep Kepemimpinan}

Kepemimpininan diterjemahkan dalam fungsinya sebagai perilaku, efektivitasnya tidak karena seruan yang mengganggu, teriakkan yang menekankan tetapi terletak pada perilaku dalam meningkatkan kepercayaan (Sutikno 2014). Hubungan setiap pekerja, cara kerja seorang pemimpin dan bawahan, dan penciptaan ketertiban pembagian kerja merupakan suatu proses kepemimpinan yang dilakukan oleh seorang pemimpin dalam mempengaruhi dan mencapai tujuan organisasinya. (Frinaldi 2018).

Bass dalam (Gibson and Cordova 1999) mendefinisikan kepemimpinan transformasional adalah kemampuan untuk memberikan inspirasi dan memotivasi semua pengikut untuk memperoleh hasil yang lebih baik dari pada yang 
Fitria Wulandari, Aldri Frinaldil Pengaruh Kepemimpinan Kepala Dinas Perempuan terhadap Budaya Kerja Pegawai pada Dinas Lingkungan Hidup Kabupaten Dharmasaya

direncanakan secara orisinil dan untuk pencapaian internal.

Stereotip sosial yang berkembang dimasrakat merupakan salah satu penghambat keterlibatan perempuan dalam hal memimpin suatu organisasi atau instansi. Sementara itu, keberan bahwa perempuan tidak mampu memimpin dibandingkan dengan laki-laki tidak dapat dibuktikan secara empiris.

Berdasarkan semua defenisi tersebut, dapat disimpulkan bahwa kepemimpinan merupakan suatu bentuk dari sebuah proses atau cara mempengaruhi individu-individu lain yang ada dalam kelompok untuk menggapai suatu tujuan bersama-sama dalam suatu situasi tertentu. Oleh sebab itulah, seorang pemimpin harus memperhatikan setiap kerja dari bawahan dan keadaan disekirar organisasi yang akan dihadapi dalam menjalankan kepemimpinannya. Serta cara perempuan dan laki-laki dalam pemimpin sangatlah berbeda.

\section{Konsep Budaya Kerja}

Menurut (Domiyandra and Rivai 2019) setiap manusia pasti akan memposisikan dirinya dalam sejarah budaya sejak jaman penjajahan hingga manusia dipandang bagaikan objek dalam beragam tingkatan budaya, yang mampu diidentifikasikan berdasarkan kuantitas dan kualitasnya. (Frinaldi 2014) menyatakan bahwa budaya kerja ialah pandangan, sikap dan perilaku seseorang atau kelompok orang yang digunakan dalam hal pekerjaan pada suatu instasni/lembaga/organisasi tertentu.

Budaya kerja dapat diartikan sebagai tingkah laku seseorang atau kelompok yang dianut dalam suatu organisasi atau lembaga atau instansi yang dipandang sebagai acuan dalam berperilaku yang dapat membentuk suatu identitas dari instansi tersebut.

\section{METODE PENELITIAN}

Dalam penelitian ini peniliti method kuantitatif yang bersifat deskriptif. Lokasi penelitian dilakukan pada Kantor Dinas Lingkungan Hidup Kabupaten
Dharmasraya. Penentuan responden menggunakan teknik total sampling yaitu mengambil semua jumlah populasi pegawai yang ada pada DLH Kabupaten Dharmasraya, dengan jumlah 62 orang pegawai. Pengumpulan data dilaksanakan dengan penyebaran angket yang berskala likert yang telah diuji validitas dan reabilitasnya. Pengolahan data menggunakan bantuan aplikasi SPSS versi 22.

\section{HASIL DAN PEMBAHASAN Profil Responden}

Dalam penelitian ini total responden adalah 62 orang pada Dinas Lingkungan Hidup Kabupaten Dharmasraya, berdasarkan data yang didapatkan saat pengisian kuesioner oleh pegawai pada Juli 2020 disajikan dalam diagram berikut:

\section{Gambar 2. Spesifik Jenis Kelamin}

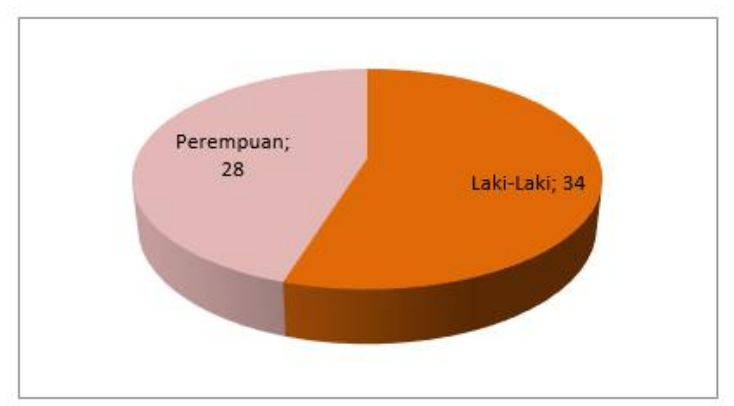

Dapat kita lihat bahwasanya besar jumlah responden yang berjenis kelamin laki-laki dan yang berjenis kelamin perempuan pada penelitian ini hampir seimbang, yaitu dengan persentase laki-laki sebesar 54,8\%, sedangkan persentase responden berjenis kelamin perempuan adalah sebesar $45,2 \%$.

\section{Gambar 3. Spesifik Berdasarkan Usia}

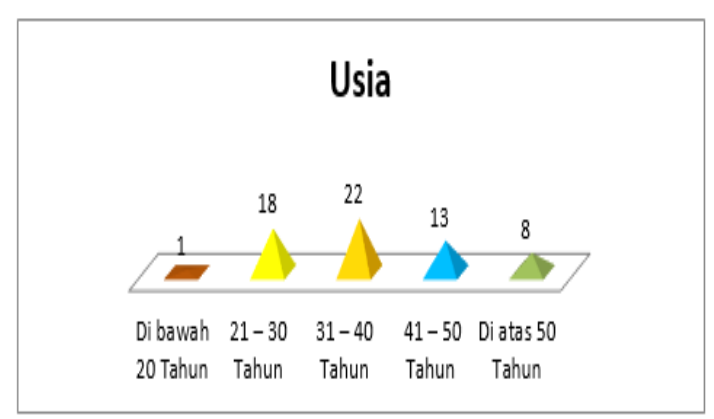


Fitria Wulandari, Aldri Frinaldil Pengaruh Kepemimpinan Kepala Dinas Perempuan terhadap Budaya Kerja Pegawai pada Dinas Lingkungan Hidup Kabupaten Dharmasaya

Adapun jumlah responden yang terbanyak berada pada rentang umur 31-40 tahun dengan persentase sebesar 35,5\%. Sedangkan untuk persentase yang terendah adalah responden dibawah 20 tahun dengan jumlah sebanyak 1 orang dan persentase sebesar $1,6 \%$.

\section{Gambar 4. Spesifik Pendidikan Terakhir}

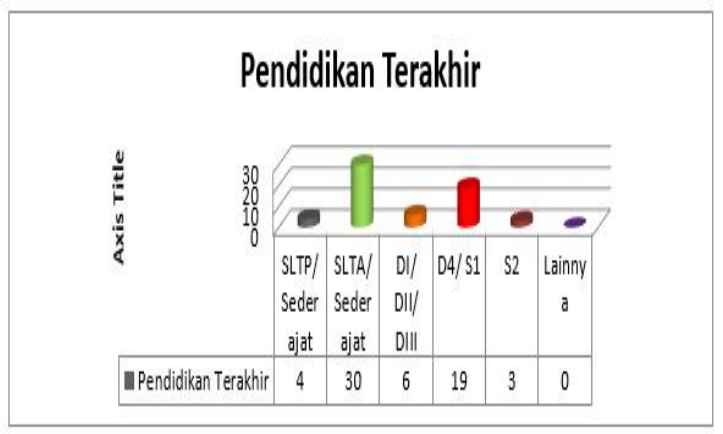

Responden yang terbanyak pada saat dilakukannya penelitian ialah responden yang telah melewati pendidikan SLTA/ Sederajat dengan persentase sebesar $48,4 \%$. Sementara itu responden yang paling sedikit berdasarkan Pendidikan terakhir adalah S2 dengan persentase $4,8 \%$.

\section{Gambar 5. Spesifik Masa Kerja}

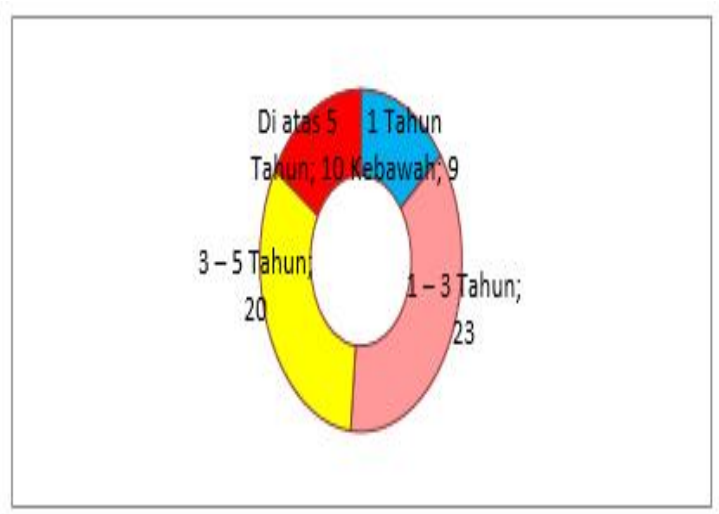

Responden yang sudah melewati masa kerja rentang $1-3$ tahun dengan persentase $37,1 \%$. Sedangkan responden yang masa kerja paling sedikit adalah rentang 1 tahun ke bawah dengan persentase $14,5 \%$.

\section{Uji Asumsi Klasik}

\section{Gambar 6. Uji Asumsi Klasik Pengaruh X terhadap Y}

Normal P-P Plot of Regression Standardized Residual

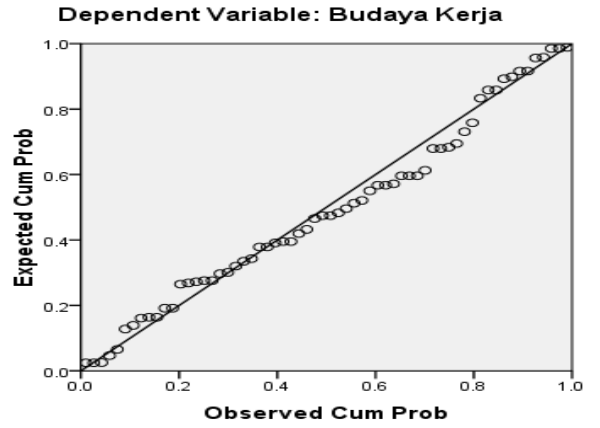

Berdasarkan gambar di atas dapat disimpulkan bahwasanya hasil data terdistribusi dengan normal, yang ditandai dengan adanya gambar titik-titik disepanjang garis. Hal ini menyatakan bahwa data dalam penelitian ini memenuhi syarat untuk dilakukan uji regresi, karena data tidak memiliki gangguan pada pendistribusiannya.

\section{Gambar 7. Uji Heteroskodestisitas}

Scatterplot

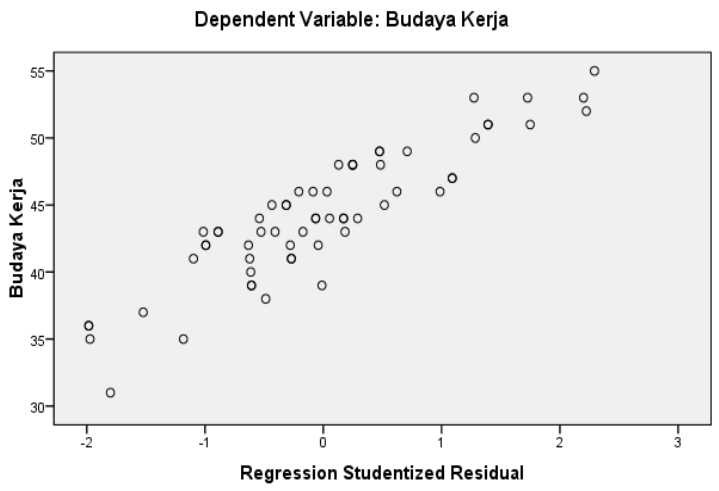

Dari hasil output di atas, maka dapat dilihat bahwa dari data penelitian ini digambarkan dengan bentuk titik-titik. Semua titik yang tesebar di atas angka nol di daerah sumbu Y.

Titik yang terletak di atas dan di bawah nol pada sumbu Y. Titik-titik tersebut tidak membentuk suatu pola tertentu. Hal ini dapat dimaknai bahwa pada data penelitian ini tidak terdapat masalah heteroskodestisitas pada variabel penelitian. 
Fitria Wulandari, Aldri Frinaldil Pengaruh Kepemimpinan Kepala Dinas Perempuan terhadap Budaya Kerja Pegawai pada Dinas Lingkungan Hidup Kabupaten Dharmasaya

Dengan kata lain, tidak adanya penyimpangan yang terjadi antara semua variabel penelitian.

\section{UJI HIPOTESIS \\ REGRESI LINIER SEDERHANA}

Tabel 2. Hasil Uji Persamaan Regresi

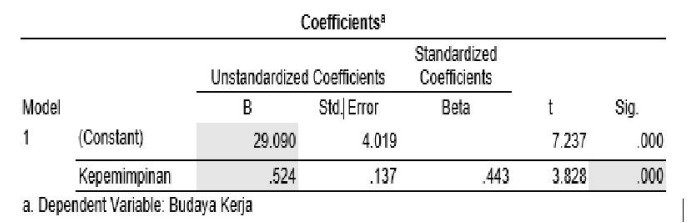

Sumber: Data Olah Penelitian, 2020

Rumus dari cara mencari Regresi

Sederhana

$\mathrm{Y}=\mathrm{a}+\mathrm{bx}$

Kepemimpinan $=29,090+0,524$

Kepemimpinan, penjelasanya sebagai berikut:

1) Nilai constant (a) adalah 29,090 maksudnya jika Kepemimpinan dikatakan nol (0) maka budaya kerja sebesar 29,090.

2) Nilai koefisien regresi variabel Kepemimpinan adalah 0,524 artinya setiap peningkatan Kepemimpinan sebesar 1 satuan dan akan meningkat budaya kerja sebesar 0,524 dan sebaliknya dengan kemungkinan variabel lainnya.

\section{Pengujian Hipotesis T-test}

Uji t pada umumnya akan menunjukkan seberapa besar pengaruh variabel independen secara individual ketika menerangkan variabel dependen. Uji t ialah prosedur yang digunakan saat menguji kebenaran ataupun kesalahan hipotesis nol (0) dan hasil sampel.

\section{Tabel 3. Hasil Uji Hipotesisi T-Test}

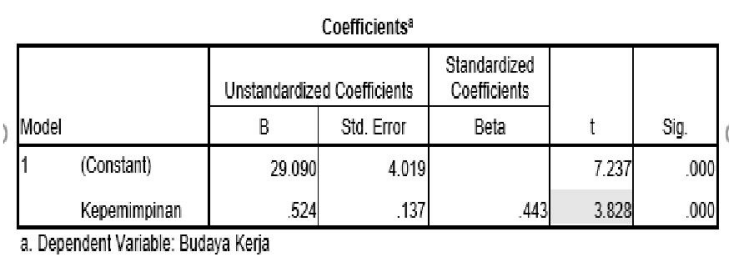

Sumber: Data Olahan Peneliti, 2020
Secara parsial variabel budaya kerja, diketahui nilai $t_{\text {tabel }}$ pada taraf signifikansi $5 \%$. Diketahui thitung 3,828>t tabel 2,400 atau sig $0,000<0,05$ untuk memahami apakah kepemimpinan berpengaruh terhadap budaya kerja pegawai pada Dinas Lingkungan Hidup Kabupaten Dharmasraya, dapat mengambil kesimpulan sebagai berikut:

$\mathrm{H}_{0} \quad$ : Hipotesis yang menyatakan tidak adanya hubungan antara variabel yang sedang dipermasalahkan diduga "tidak ada pengaruh kepemimpinan kepala dinas perempuan terhadap budaya kerja pegawai pada DLH Kabupaten Dharmasraya"

$\mathrm{H}_{\mathrm{a}} \quad$ : hipotesis yang menyatakan adanya hubungan antara variabel yang sedang dipermasalahkan, diduga "adanya pengaruh kepemimpinan kepala dinas perempuan terhadap budaya kerja pegawai pada DLH Kabupaten Dharmasraya"

Berikut adalah dasar pengambilan keputusan apakah kepemipinan kepala dinas perempuan berpengaruh terhadap budaya kerja pegawai atau tidak.

Dengan demikian dapat kita ketahui bahwa nilai $t_{\text {thitung }} 3,828>t_{\text {tabel }} 2,400$ atau sig 0,000 $<0,05$, sehingga $\mathrm{H}_{0}$ tidak diterima dan $\mathrm{H}_{\mathrm{a}}$ diterima, maka itu artinya kepemimpinan kepala dinas perempuan berpengaruh signifikan terhadap budaya kerja.

\section{Uji Koefisien Determinasi $\mathbf{R}^{\mathbf{2}}$}

Pengujian hipotesis menggunakan koefisien determinasi $\left(\mathrm{R}^{2}\right)$ bertujuan untuk mengetahui persentase variabel $\mathrm{X}$ secara bersamaan mampu menjelaskan variaber $Y$. Untuk melihat koefisien determinasi, dapat dilihat dari tabel dibawah:

\section{Tabel 4. Hasil Uji Koefisien Determinasi}

\begin{tabular}{|l|c|r|r|r|r|}
\hline Model & $R$ & R Square & $\begin{array}{c}\text { Adjusted R } \\
\text { Square }\end{array}$ & $\begin{array}{c}\text { Std. Error of the } \\
\text { Estimate }\end{array}$ & Durbin-Watson \\
\hline 1 & $.443^{a}$ & .196 & .183 & 4.482 & 1.600 \\
\hline
\end{tabular}
a. Predictors: (Constant), Kepenimpinan
b. Dependent Variable: Budaya Kerja

Sumber: Data Olahan Peneliti, 2020

Hasil ouput statistik menunjukkan bahwa, uji $\mathrm{R}^{2}$ antara variabel 
Fitria Wulandari, Aldri Frinaldil Pengaruh Kepemimpinan Kepala Dinas Perempuan terhadap Budaya Kerja Pegawai pada Dinas Lingkungan Hidup Kabupaten Dharmasaya

kepemimpinan dengan variabel budaya kerja dengan hasil sebesar ,196, dari pada itu variabel kepemimpinan bisa menegaskan bahwa variabel budaya kerja sebsar $19,6 \%$ sedangkan sisanya $81,4 \%$ dijelaskan pada bagian variabel lain yang tidak diteliti pada penelitian ini.

\section{PENUTUP}

Berdasarkan dari hasil penelitian yang telah dilakukan pada Dinas Lingkungan Hidup Kabupaten Dharmasraya, dan berdasarkan analisis data maka dapat disimpulkan sebagai berikut:

1. Berdasarkan uji regresi sederhana $Y=$ $29,090+0,524 \times$ nilai konstanta (a) sebesar 29,090 artinya apabila kepemimpinan diasumsikan nol (0) maka budaya kerja sebsar 29,090, nilai koefisien regresi variabel kepemimpinan sebesar 0,524 adalah setiap meningkatnya kepemimpinan kepala dinas perempuan sebsar 1 satuan, maka akan meningkat budaya kerja sebesar 0,524 dan begitupula sebaliknya dengan asumsi variabel dependen.

2. Diketahui hasil uji t parsial thitung $3,828>$ $t_{\text {tabel }} 2,400$ atau sig $0,000<0,05$, maka kepemimpinan kepala dinas perempuan berpengaruh signifikansi terhadap budaya kerja.

3. Dari hasil penelitian uji koefisien determinasi $\left(\mathrm{R}^{2}\right)$ diketahui uji koefisien korelasi (R) antara variabel kepemimpinan (X) dengan variabel budaya kerja (Y) didapat sebesar 0,196 sedangkan variabel bebas mampu menjelaskan variabel terikan sebesar $19,6 \%$.

4. Sehingga dapat diperoleh hasil bahwa kepemimpinan kepala dinas perempuan berpengaruh terhadap budaya kerja pegawai pada Dinas Lingkungan Hidup Kabupaten Dharmasraya, hal ini dibuktikan dari hasil thitung $\geq t_{\text {tabel }}$.

\section{DAFTAR KEPUSTAKAAN}

Domiyandra, Rimon, and Hariv Amali Rivai. 2019. "Pengaruh Kepemimpinan Etis(Ethical Leadership),Budaya Organisasi, Dan Penghargaan(Rewards) Terhadap Keterikatan Kerja(Work Engagement) Account Representative (Ar) Pada Kpp Pratama Di Lingkungan Kanwil Djp 'X."' Jurnal Stie Semarang.

Fitri, A., A. Frinaldi, and Erianjoni. 2019. “Wali Nagari Women's Leadership Style in the Development of Nagari Government in Nagari Tigo Balai, Matur Sub-District, Agam Regency." IOP Conference Series: Earth and Environmental Science 314(1).

Frinaldi, Aldri. 2014. "Pengaruh Budaya Kerja Pegawai Negeri Sipil Terhadap Pelayanan Publik Di Dinas Catatan Sipil Dan Kependudukan Kota Payakumbuh." Humanus.

Frinaldi, Aldri. 2018. "Dan Budaya Kerja." in Budaya Kerja.

Gibson, D. E., and D. I. Cordova. 1999. "Women's and Men's Role Models: The Importance of Exemplars." in Mentoring dilemmas: Developmental relationships within multicultural organizations. Applied social research.

SM, A. E., and A. T. Naumi. 2019. "Performa Pemimpin Perempuan Di Parlemen.” Jurnal Professional.

Sutikno, Sobry. 2014. "Pemimpin Dan Kepemimpinan." Pemimpin Dan Kepemimpinan. 